\title{
Popular Music Studies in Japan: Reviewing the Journal Popular Music Studies
}

\author{
Akitsugu Kawamoto \\ Ferris University \\ kawamotoa@ferris.ac.jp
}

\section{Introduction}

"The year 1987 will probably be commemorated some day in Japan as the first year when this interest [in popular music studies] was formally institutionalized," wrote Toru Mitsui, one of the founding members of Nihon popyura ongaku gakkai ("Japanese Association for the Study of Popular Music", JASPM) in 1988 (Mitsui 1988). ${ }^{1}$ Mitsui was right. Thirty years later in 2018, JASPM organized as part of its 30th Annual Meeting a symposium entitled "The Thirty Years of Popular Music Studies in Japan", suggesting the growing scholarly interest in popular music since the beginning of the Association. The only major Japanese society to specialize in popular music studies, JASPM has since held national and regional conferences quite regularly and, from 1997 on, annually published its house journal entitled Popyurā ongaku kenkyū ("Popular Music Studies"). Recently, other related societies in Japan, such as Nihon ongaku gakkai ("Musicological Society of Japan"), Tōyō ongaku gakkai ("The Society for Research in Asiatic Music"), and Nihon shakai gakkai ("The Japan Sociological Society"), also included popular-music papers in their conference programs. Popular music studies has certainly increased its presence in Japanese academia. ${ }^{2}$

In an attempt to introduce popular music studies in Japan to the readership of the IASPM Journal, I will review the aforementioned JASPM journal, Popular Music Studies, and try to characterize its articles from the following viewpoints: particularism, Japanologism, and sociologism. ${ }^{3}$ At the end I will express my hope for the future articles of the journal to have more variety in terms of themes, perspectives, and methods, than they have now. 


\section{Particularism}

The reader of Popular Music Studies would almost immediately notice the particularism, as opposed to the generalism, underpinning many of its articles. They focus on a specific phenomenon found in a particular location, audience, industry, culture, media, and music, and sometimes it is the goal of the study to provide detailed data of such a phenomenon. An example is Yoshimasa Kijima's "The Public Sense of Street Musicians: Using the Example of Narrator-Singer Guitarists in Shinsaibashi" (2006). Through field research and interviews with the musicians playing in the narrowly limited area (with a radius of about $100 \mathrm{~m}$ ) of Shinsaibashi, downtown of Osaka, Japan in 2002 and 2004, he collected detailed data regarding the performers, performances, audiences, and receptions. They are shown in tables and graphs. Comparing the data from 2002 with that of 2004, Kijima appears to conclude with three observations: (1) the musicians feel comfortable on the street, (2) street performances have recently been accepted as culture, and (3) the performers dream of a huge success in becoming superstars. Though these observations are fair enough, one wonders if the same can be said about the street musicians of other places, whether in Japan or in the world. Kijima seems to emphasize the specificities of the data collected from this particular place, while no discussion is made as to how specific these data are in comparison with the data that could be collected from other places. In this sense, his article is more an instance of particularism than that of generalism, even if an underlying argument might potentially claim for a critical view toward the general presumptions.

Many other articles in the journal are of this type; particularism can be observed everywhere. Examples include, but are not limited to, Tadasu Tsuruta's "The Interlocking Development of Rural Folk Songs and Urban Popular Songs in Central Thailand" (2000), Toshiyuki Masubuchi's "The Industrialization Process of Music in a Local City of Japan: The Case of Fukuoka" (2005), Shuji Kamimoto's "Using Dancehall As a Trigger for Empowering the Local Residents: A Case Study of 'Treasures of Wakasa'" (2014), and Susumu Oyama's "The Portrayal of the Northern Soul Scene in Blues \& Soul in the Early 1970s: The Appreciation of Black Singers in 'The Torch Story'" (2017).

Several articles are more generalist in orientation. Hiroshi Ogawa's "Difficulties and Problems facing Popular Music Studies" (1997) and Yoshiji Awatani's "From 'the Spirit of the Times' of Rock to Audiences: Cultural Studies and Popular Music" (1998) are obvious examples, but there are few more examples like these. Some generalist views, as opposed to particularist ones, have certainly been expressed in other forms of publication such as books of anthologies and monographs. However, there are customarily no significant peer reviews for book publications in Japan. Overall in the country, we find few scholarly-accepted, generalist writings on popular music.

\section{Japanologism}

Japanese music, musicians, and/or music culture is the main subject of so many articles in Popular Music Studies, not surprisingly. Among the twenty-two volumes presently being reviewed, eighteen include at least one article about Japanese music, whereas only twelve volumes include articles on the music outside Japan. Reiichi Kimoto's "Networks in Japanese Rap Music: A Case Study of Local Rap Groups" (2003) is an example of the focus on Japanese content. As the title clearly indicates, it is a study of Japanese local rap groups, analyzing the human networks that seem to mediate between the global rap music imported into Japan and its 
localized forms in specific places. The study seems to be geared towards an understanding of specifically Japanese phenomenon, rather than towards an understanding of the global phenomenon of rap music itself.

Many other articles are kinds of Japanology, which is apparent in their titles, such as Ayako Kato's "A Quantitative Analysis on Structural Change in Japanese Record Business: Transformation of Inter-Organizational Relations in Triangle Structure" (2011), and Yusuke Taguchi's "Brass Band Denied Jinta: Gaze of Modernization of Wind Band Music in Early Showa Era" (2017). Even if the title of a paper suggests a global topic, the body text often focuses on Japanese events. Fumiaki Taniguchi's article, entitled "Keyboard' for the Users of Digital Synthesizer: A Case Study of Sound-Making Practice in 1980s" (2008), analyzes the discourse of Japanese keyboardists in the 1980s, not necessarily dealing with the discourse of nonJapanese musicians.

Some articles study Japanese music reception in other countries: Motoko Yabuki's "Japanese Popular Music in Taiwan through History of Cover Songs" (2004) and Yukari Nakahara's "Japanese Popular Music and Night Clubs in Hawai'i: 1950s-1970s" (2004), to name a couple. On the other hand, Akira Tomita's "Pan in Japan: The Acceptance and Diffusion of Steelpan in Japan" (2001) is a study of a foreign musical instrument as it is used in Japanese popular-music practices. Taken at face value, these articles may be seen as studies of not only Japan but also other countries, but the primary aim of these articles is specifically to better understand Japanese music and its culture.

Several articles in Popular Music Studies are devoted to studies of music outside Japan. Ritsuko Toita's "Relation Between Words and Melody in Songs of Prūvert" (1997), Tadayuki Tsuchiya's "On Interpreting 'Yesterday Once More" (2000), Tomohiro Kurita's "Cultural Sociology of 'Eminem': How Indexes of Hip-Hop/Rock Authenticity and Legitimacy Operate to Interpret 'Hate Speech'" (2007), and Mari Nagatomi's "Music is Universal': Foreign Songwriters in Nashville in the Era of Cultural Globalization" (2015) are important studies of American and European music and/or musicians.

It must be admitted, however, that we find a certain level of domestic, rather than global, tendencies in the choice of subject in the JASPM articles. While it is quite natural to see many Japanese scholars studying the music of their country, considering the scope of music outside Japan as well would provide a richer context for studies on Japanese music.

\section{Sociologism}

The most prevalent methodology employed in the journal articles is, without a doubt, sociology. The very opening article for the first volume is the aforementioned essay by the sociologist Hiroshi Ogawa, entitled "Difficulties and Problems facing Popular Music Studies" (1997). Ogawa describes popular music as our daily experience, and insists that popular music studies must explain why it is so "popular" and enhance our understanding of our own culture. This powerful "call" for sociological studies is "responded" to by many strong articles from sociological perspectives, such as: Katsuya Minamida's "Three Indicators in the Rock Music Culture: Toward a Methodology of Cultural Sociology" (1998), Akinori Ideguchi's "The Street Musician as NON-BUSKER: Focusing on the Function of the Others" (2004), Toyoichi Nozawa's "Groove as Process of Communication: A Case Study of Japanese Gospel Singing Groups" (2009), and Kouki Shibadai's "The Making of 
Standard Repertoire in Japanese Popular Music: In the Case of 'Tubasa wo Kudasai'" (2013).

Of course sociology is not the sole method for all the journal articles; there are also studies from the historical and ethnographical perspectives, such as Shin Aoki's "Singing Exoticism: A Historical Anthropology of Gl Songs, 'China Night' and 'Japanese Rumba'" (2012) and Jun Ishibashi's "Objectification of Folk Culture and Warranty Policy of Authenticity: A Case Study on a Movement for Afro-Venezuelan Cultural Revitalization in San Mill6n, Venezuela" (1999). Sometimes we find media studies, such as Yudai Fukuda's "On Charles Cros' Phonograph Theory, and his Notion of Sound Representation" (2009) and Yasuharu Akiyoshi's "Physiognomy of the Singing Voice: Medium Effect on the Discourse of 'the Racial Voice' in 1920s" (2010). Occasionally there is an interesting thread of debates on the ontology of popular music: Satoshi Masuda's "What is 'Musical Work' in Popular Music?: An Attempt towards Semiotic Studies" (1997), Susumu Imai's "Ontology of Popular Music: Track, Song, Performance" (2011), and Kentaro Tanabe's "A Survey of Ontology of Music in Analytic Aesthetics" (2017).

While we find at least some musicological presentations at the international conferences of the IASPM, we find very few musicological papers in the journal and conferences of JASPM. In addition to Toita's aforementioned article on the music of Prevйrt, there are only a couple more musicological studies: Masato Yako's "Classification of Rhythm Patterns by Using Computer" (1998) and Fumikazu Taniguchi's "A Musical Analysis of DJ Performances in Turntablism" (2003). The growth of this area of research, musicological studies, would enhance our understanding of popular music in Japan in my opinion.

As shown above, the journal has some notable tendencies towards particularism, Japanologism, and sociologism. This is not necessarily to say that there are no generalist views, no studies of foreign musics, or no other methodologies employed by Japanese scholars at all. Published anthologies and monographs in the form of books certainly include more generalist essays, non-domestic music studies, and non-sociological work (see, for example, Toya 2003 and Mitsui 2005). However, the three tendencies are quite apparent in those refereed articles in the twenty-two published volumes of Popular Music Studies. This might suggest that, at this point of Japanese academia, generalist discussions, studies on non-Japanese music, and non-sociological perspectives are not popular approaches. An exploration of why this is so is beyond the scope of this present article, but I would hope to see more of this sort of work in the future. That would hopefully encourage more variety in popular music studies in Japan, which would then lead to a richer development of the field.

\section{Endnotes}

(1) JASPM is not the Japanese branch of the IASPM. JASPM is much larger organization than IASPM-Japan, but it is for those who would like to present and publish mostly in Japanese and not necessarily in English, so their work is rarely visible outside Japan.

(2) It should also be mentioned that popular music studies in Japan have stronger presence in the global academia than before, with an increasing number of Japanese popular music scholars presenting papers at international conferences of the International Council of Traditional Music, the IASPM-International, and the Inter-Asia Popular Music Studies group.

(3) The journal generally consists of scholarly articles, research notes, review articles, book reviews, and conference reports, almost all written in Japanese. For the purposes of this present paper, I will choose the first two for review: scholarly articles and research notes. 
Of these two, the main focus is placed on the first. I will refer to JASPM articles by their English titles, mostly translated by the authors themselves. I will omit their original Japanese titles, both in body text and bibliography, so as to facilitate the understanding of the readership of this present journal.

\section{References}

Akiyoshi, Y. 2010. Physiognomy of the Singing Voice: Medium Effect on the Discourse of "the Racial Voice" in 1920s. Popular Music Studies 14: 3-16.

Aoki, S. 2012. Singing Exoticism: A Historical Anthropology of GI Songs, "China Night" and "Japanese Rumba". Popular Music Studies 16: 3-16.

Awatani. Y. 1998. From "the Spirit of the Times" of Rock to Audiences: Cultural Studies and Popular Music. Popular Music Studies 2: 23-34.

Fukuda, Y. 2009. On Charles Cros' Phonograph Theory, and His Notion of Sound Representation. Popular Music Studies 13: 3-16.

Ideguchi, A. 2004. The Street Musician as NON-BUSKER: Focusing on the Function of the Others. Popular Music Studies 8: 3-16.

Imai, S. 2011. Ontology of Popular Music: Track, Song, Performance. Popular Music Studies 15: 23-42.

Ishibashi, J. 1999. Objectification of Folk Culture and Warranty Policy of Authenticity: A Case Study on a Movement for Afro-Venezuelan Cultural Revitalization in San Millán, Venezuela. Popular Music Studies 3: 2-18.

Kamimoto, S. 2014. Using Dancehall As a Trigger for Empowering the Local Residents: A Case Study of "Treasures of Wakasa". Popular Music Studies 18: 3-17.

Kato, A. 2011. A Quantitative Analysis on Structural Change in Japanese Record Business: Transformation of Inter-Organizational Relations in Triangle Structure. Popular Music Studies 15: 3-22.

Kijima, Y. 2006. The Public Sense of Street Musicians: Using the Example of Narrator-Singer Guitarists in Shinsaibashi. Popular Music Studies 10: 16-39.

Kimoto, R. 2003. Networks in Japanese Rap Music: A Case Study of Local Rap Groups. Popular Music Studies 7: 3-14.

Kurita, T. 2007. Cultural Sociology of "Eminem": How Indexes of Hip-Hop/Rock Authenticity and Legitimacy Operate to Interpret "Hate Speech". Popular Music Studies 11: 3-17.

Masubuchi, T. 2005. The Industrialization Process of Music in a Local City of Japan: The Case of Fukuoka. Popular Music Studies 9: 3-21.

Masuda, S. 1997. What is "Musical Work" in Popular Music?: An Attempt Towards Semiotic Studies. Popular Music Studies 1: 22-34.

Minamida, K. 1998. Three Indicators in the Rock Music Culture: Toward a Methodology of Cultural Sociology. Popular Music Studies 2: 35-50.

Mitsui, T. 1988. Popular Music Studies in Japan. Popular Music 7(1): 103.

Mitsui, T. Ed. 2005. Popyurā ongaku to akademizumu (Popular Music and Academism). Tokyo: Ongaku no Tomo Sha.

Nagatomi, M. 2015. "Music is Universal": Foreign Songwriters in Nashville in the Era of Cultural Globalization. Popular Music Studies 19: 3-14.

Nakahara, Y. 2004. Japanese Popular Music and Night Clubs in Hawai'i: 1950s1970s. Popular Music Studies 8: 35-44.

Nozawa, T. 2009. Groove as Process of Communication: A Case Study of Japanese Gospel Singing Groups. Popular Music Studies 13: 17-30. 
Ogawa, H. 1997. Difficulties and Problems facing Popular Music Studies. Popular Music Studies 1: 2-6.

Oyama, S. 2017. The Portrayal of the Northern Soul Scene in Blues \& Soul in the Early 1970s: The Appreciation of Black Singers in "The Torch Story". Popular Music Studies 21: 3-18.

Shibadai, K. 2013. The Making of Standard Repertoire in Japanese Popular Music: In the Case of "Tubasa wo Kudasai". Popular Music Studies 17: 17-30.

Taguchi, Y. 2017. Brass Band Denied Jinta: Gaze of Modernization of Wind Band Music in Early Showa Era. Popular Music Studies 21: 19-33.

Tanabe, K. 2017. A Survey of Ontology of Music in Analytic Aesthetics. Popular Music Studies 21: 35-43.

Taniguchi, F. 2008. "Keyboard" for the Users of Digital Synthesizer: A Case Study of Sound-Making Practice in 1980s. Popular Music Studies 12: 3-17.

Taniguchi, F. 2003. A Musical Analysis of DJ Performances in Turntablism. Popular Music Studies 7: 15-34.

Toita, R. 1997. Relation Between Words and Melody in Songs of Prūvert. Popular Music Studies 1: 7-21.

Tomita, A. 2001. Pan in Japan: The Acceptance and Diffusion of Steelpan in Japan. Popular Music Studies 5: 18-36.

Toya, M. Ed. 2003. Popyurā ongaku eno manazashi (Views Toward Popular Music). Tokyo: Keiso Shobo.

Tsuchiya, T. 2000. On Interpreting "Yesterday Once More". Popular Music Studies 4: 20-30.

Tsuruta, T. 2000. The Interlocking Development of Rural Folk Songs and Urban Popular Songs in Central Thailand. Popular Music Studies 4: 2-19.

Yabuki, M. 2004. Japanese Popular Music in Taiwan through History of Cover Songs. Popular Music Studies 8: 17-34.

Yako, M. 1998. Classification of Rhythm Patterns by Using Computer. Popular Music Studies 2: 2-22. 